NIST NCSTAR 1-1I

Federal Building and Fire Safety Investigation of the World Trade Center Disaster

\title{
Post-Construction Modifications to Fire Protection, Life Safety, and Structural Systems of World Trade Center 7
}

Raymond A. Grill Duane A. Johnson

David A. Fanella 

Federal Building and Fire Safety Investigation of the World Trade Center Disaster

\section{Post-Construction Modifications to Fire Protection, Life Safety, and Structural Systems of World Trade Center 7}

Raymond A. Grill

Duane A. Johnson

David A. Fanella

Rolf Jensen \& Associates, Inc.

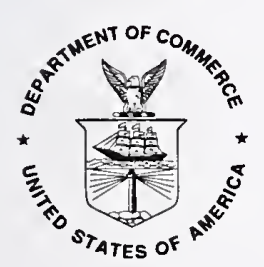

U.S. Department of Commerce

Carlos M. Gutierrez, Secretary

Technology Administration

Michelle O'Neill, Acting Under Secretary for Technology

National Institute of Standards and Technology

William Jeffrey, Director 


\section{Disclaimer No. 1}

Certain commercial entities, equipment, products, or materials are identified in this document in order to describe a procedure or concept adequately or to trace the history of the procedures and practices used. Such identification is not intended to imply recommendation, endorsement, or implication that the entities, products, materials, or equipment are necessarily the best available for the purpose. Nor does such identification imply a finding of fault or negligence by the National Institute of Standards and Technology.

\section{Disclaimer No. 2}

The policy of NIST is to use the International System of Units (metric units) in all publications. In this document, however, units are presented in metric units or the inch-pound system, whichever is prevalent in the discipline.

\section{Disclaimer No. 3}

Pursuant to section 7 of the National Construction Safety Team Act, the NIST Director has determined that certain evidence received by NIST in the course of this Investigation is "voluntarily provided safety-related information" that is "not directly related to the building failure being investigated" and that "disclosure of that information would inhibit the voluntary provision of that type of information" (15 USC 7306c).

In addition, a substantial portion of the evidence collected by NIST in the course of the Investigation has been provided to NIST under nondisclosure agreements.

\section{Disclaimer No. 4}

NIST takes no position as to whether the design or construction of a WTC building was compliant with any code since, due to the destruction of the WTC buildings, NIST could not verify the actual (or as-built) construction, the properties and condition of the materials used, or changes to the original construction made over the life of the buildings. In addition, NIST could not verify the interpretations of codes used by applicable authorities in determining compliance when implementing building codes. Where an Investigation report states whether a system was designed or installed as required by a code provision, NIST has documentary or anecdotal evidence indicating whether the requirement was met, or NIST has independently conducted tests or analyses indicating whether the requirement was met.

\section{Use in Legal Proceedings}

No part of any report resulting from a NIST investigation into a structural failure or from an investigation under the National Construction Safety Team Act may be used in any suit or action for damages arising out of any matter mentioned in such report (15 USC 281a; as amended by P.L. 107-231).

National Institute of Standards and Technology National Construction Safety Team Act Report 1-1I Natl. Inst. Stand. Technol. Natl. Constr. Sfty. Tm. Act Rpt. 1-1l, 46 pages (September 2005) CODEN: NSPUE2

\section{U.S. GOVERNMENT PRINTING OFFICE WASHINGTON: 2005}

For sale by the Superintendent of Documents, U.S. Government Printing Office Internet: bookstore.gpo.gov - Phone: (202) 512-1800 - Fax: (202) 512-2250 Mail: Stop SSOP, Washington, DC 20402-0001 


\section{ABSTRACT}

This report was prepared to support the analysis of building and fire codes and standards of the National Institute of Standards and Technology World Trade Center (WTC) Investigation. This report was prepared to support the overall objective of determining how and why WTC 7 collapsed. The purpose of this report is to document modifications and/or repairs of the fire protection, life safety, and structural framing systems of WTC 7.

Keywords: Beams, building modifications, cover plates, fire alarm, fire protection, fire safety, fire sprinklers, floor slab openings, high-rise buildings, life safety, means of egress, pressurization, structural framing, tenant alterations, voice communication, web openings, wide-flange T-sections, World Trade Center. 
This page intentionally left blank. 


\section{TABLE OF CONTENTS}

Abstract iii

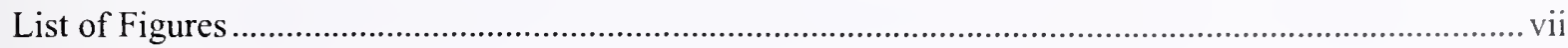

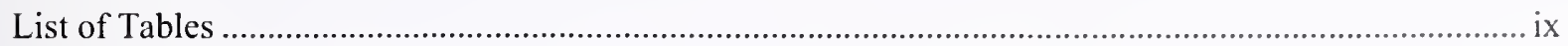

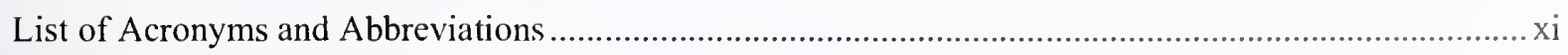

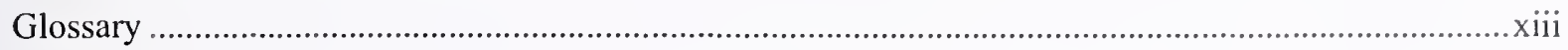

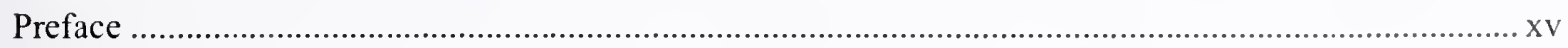

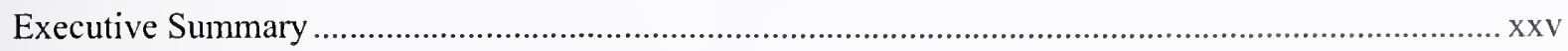

Chapter 1

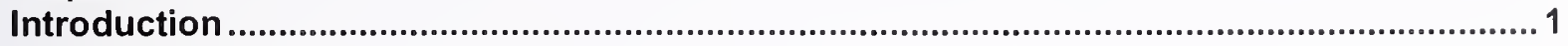

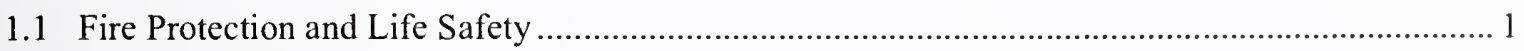

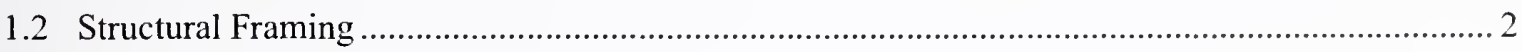

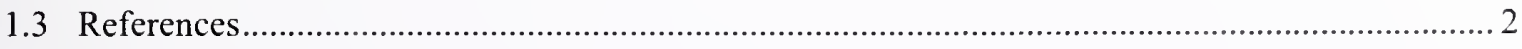

Chapter 2

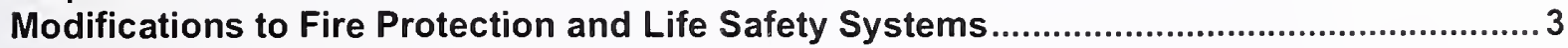

Chapter 3

Structural Modifications due to Tenant Alterations ....................................................... 11

Chapter 4

Openings Made in Floor Slabs ........................................................................................ 15

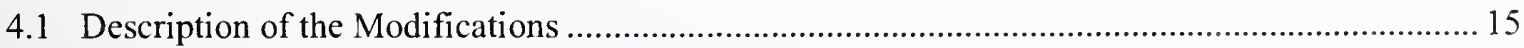

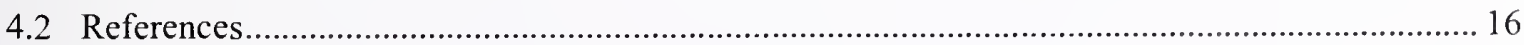

Chapter 5

Modifications Made to Beam Webs and Flanges ....................................................... 17 
This page intentionally left blank. 


\section{LIST OF FIGURES}

Figure $\mathrm{P}-1$. The eight projects in the federal building and fire safety investigation of the WTC disaster. 
This page intentionally left blank. 


\section{LIST OF TABLES}

Table P-1. Federal building and fire safety investigation of the WTC disaster. ................................ xvi

Table P-2. Public meetings and briefings of the WTC Investigation............................................. xix

Table 2-1. Summary of modifications to WTC 7 fire protection and life safety systems...................... 3

Table 3-1. Modifications made due to tenant alterations. ......................................................... 11

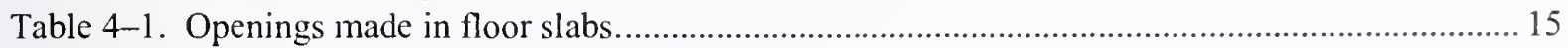

Table 5-1. Modifications made to beam webs and flanges. ..................................................... 17 
This page intentionally left blank. 


\section{LIST OF ACRONYMS AND ABBREVIATIONS}

\section{Acronyms}

$\begin{array}{ll}\text { ASTM } & \text { ASTM International } \\ \text { BCNYC } & \text { Building Code of the City of New York (Local Law No. 76) } \\ \text { HVAC } & \text { heating, ventilating, and air conditioning } \\ \text { NFPA } & \text { National Fire Protection Association } \\ \text { NIST } & \text { National Institute of Standards and Technology } \\ \text { PANYNJ } & \text { Port Authority of New York and New Jersey } \\ \text { WTC 1 } & \text { World Trade Center 1 (North Tower) } \\ \text { WTC 2 } & \text { World Trade Center 2 (South Tower) } \\ \text { WTC 7 } & \text { World Trade Center 7 }\end{array}$

\section{Abbreviations}

ft $\quad$ foot

in. inch

WT15 $\times 74 \quad$ American Institute of Steel Construction/ASTM standard abbreviation for a box (tube) beam of cross section $15 \mathrm{in.} \mathrm{by} 74 \mathrm{in.}$

WT24x55 American Institute of Steel Construction/ASTM standard abbreviation for a wide flange beam of cross section 24 in. flange and 55 in. web. 
This page intentionally left blank. 


\section{GLOSSARY}

active fire protection - A mcans to hclp prevent the loss of lifc and property from firc by cxtinguishing, suppressing, or controlling a fire through functional systcms. Sprinkler systems, fire alarm systcms, and smoke control systems are examples of active fire protection.

area of refuge - A floor area to which egress is made through a horizontal cxit or supplemental vertical exit.

combustible - A material that is not determincd to be noncombustible.

damper - A device installed in heating, ventilating, and air conditioning ductwork used to prevent the spread of fire and/or smoke. Dampers are provided to maintain a fire resistance rating of the assembly being penetrated.

detector - An initiation device that automatically detects a change in state, such as presence of smoke, high temperature, or abnormal rate of temperature rise.

fire alarm system - A system, automatic or manual, arranged to give a signal indicating a fire emergency and initiate the appropriate response.

fire resistance rating - The time in hours that materials or their assemblies will withstand fire exposure as determined by a fire test.

fireproofing - Materials or assemblies used to provide a fire resistance rating to a building component.

firestop - A solid or compact, tight closure to retard the spread of flames or hot gases within concealed spaces.

initiation device - A system component that originates a change-in-state signal in the fire alarm system. An initiation device begins the life safety processes, such as evacuation; heating, ventilating, and air conditioning shut down; elevator recall, etc.

manual fire alarm box - A manually operated initiation device that originates a change-in-state signal in the fire alarm system.

means of egress - A continuous and unobstructed path of vertical and horizontal travel from any point in a building to a public way. The means of egress consist of the exit access, the exit, and the exit discharge.

noncombustible - A material that, in the form in which it is used in construction, will not ignite and burn when subjected to fire. However, any material which liberates flammable gas when heated to any temperature up to $1,380^{\circ} \mathrm{F}$ for $5 \mathrm{~min}$ shall not be considered noncombustible.

notification appliance - A fire alarm system component such as a bell, horn, speaker, or strobe that provides audible, tactile, or visible outputs, or any combination thereof. 
passive fire protection - Fire protection features that are incorporated into the building construction or building materials that do not rely on active fire protection methods to limit fire ignition, fire growth, or material failure. Fire separations and divisions, sprayed-on fire proofing, and enclosing structural members with noncombustible materials are examples of passive fire protection.

smoke and heat venting - A process used to move products of combustion to the outdoor air. 


\section{Preface}

\section{Genesis of This Investigation}

Immediately following the terrorist attack on the World Trade Center (WTC) on Scptember 11, 2001, the Federal Emergency Management Agency (FEMA) and the American Society of Civil Engineers began planning a building performance study of the disastcr. The wcck of October 7, as soon as the rescue and search efforts ceased, the Building Performancc Study Team went to the site and began its assessment. This was to be a brief effort, as the study team consisted of experts who largely volunteercd their time away from their other professional commitments. The Building Pcrformance Study Team issued its report in May 2002, fulfilling its goal "to determinc probable failure mechanisms and to identify areas of future investigation that could lead to practical measurcs for improving the damage resistance of buildings against such unforeseen events."

On August 21, 2002, with funding from the U.S. Congress through FEMA, the National Institute of Standards and Technology (NIST) announced its building and fire safcty investigation of the WTC disaster. On October 1, 2002, the National Construction Safety Team Act (Public Law 107-231), was signed into law. The NIST WTC Investigation was conducted under the authority of the National Construction Safety Team Act.

The goals of the investigation of the WTC disaster were:

- To investigate the building construction, the materials used, and the technical conditions that contributed to the outcome of the WTC disaster.

- To serve as the basis for:

- Improvements in the way buildings are designed, constructed, maintained, and used;

- Improved tools and guidance for industry and safety officials;

- Recommended revisions to current codes, standards, and practices; and

- Improved public safety.

The specific objectives were:

1. Determine why and how WTC 1 and WTC 2 collapsed following the initial impacts of the aircraft and why and how WTC 7 collapsed;

2. Determine why the injuries and fatalities were so high or low depending on location, including all technical aspects of fire protection, occupant behavior, evacuation, and emergency response;

3. Determine what procedures and practices were used in the design, construction, operation, and maintenance of WTC 1, 2, and 7; and

4. Identify, as specifically as possible, areas in current building and fire codes, standards, and practices that warrant revision. 
NIST is a nonregulatory agency of the U.S. Department of Commerce's Technology Administration. The purpose of NIST investigations is to improve the safety and structural integrity of buildings in the United States, and the focus is on fact finding. NIST investigative teams are authorized to assess building performance and emergency response and evacuation procedures in the wake of any building failure that has resulted in substantial loss of life or that posed significant potential of substantial loss of life. NIST does not have the statutory authority to make findings of fault nor negligence by individuals or organizations. Further, no part of any report resulting from a NIST investigation into a building failure or from an investigation under the National Construction Safety Team Act may be used in any suit or action for damages arising out of any matter mentioned in such report (15 USC 281a, as amended by Public Law 107-231).

\section{Organization of the Investigation}

The National Construction Safety Team for this Investigation, appointed by the then NIST Director, Dr. Arden L. Bement, Jr., was led by Dr. S. Shyam Sunder. Dr. William L. Grosshandler served as Associate Lead Investigator, Mr. Stephen A. Cauffman served as Program Manager for Administration, and Mr. Harold E. Nelson served on the team as a private sector expert. The Investigation included eight interdependent projects whose leaders comprised the remainder of the team. A detailed description of each of these eight projects is available at http://wtc.nist.gov. The purpose of each project is summarized in Table $\mathrm{P}-1$, and the key interdependencies among the projects are illustrated in Fig. $\mathrm{P}-1$.

Table P-1. Federal building and fire safety investigation of the WTC disaster.

\begin{tabular}{|c|c|}
\hline Technical Area and Project Leader & Project Purpose \\
\hline $\begin{array}{l}\text { Analysis of Building and Fire Codes and } \\
\text { Practices; Project Leaders: Dr. H. S. Lew } \\
\text { and Mr. Richard W. Bukowski }\end{array}$ & $\begin{array}{l}\text { Document and analyze the code provisions, procedures, and } \\
\text { practices used in the design, construction, operation, and } \\
\text { maintenance of the structural, passive fire protection, and } \\
\text { emergency access and evacuation systems of WTC } 1,2 \text {, and } 7 \text {. }\end{array}$ \\
\hline $\begin{array}{l}\text { Baseline Structural Performance and } \\
\text { Aircraft Impact Damage Analysis; Project } \\
\text { Leader: Dr. Fahim H. Sadek }\end{array}$ & $\begin{array}{l}\text { Analyze the baseline performance of WTC } 1 \text { and WTC } 2 \text { under } \\
\text { design, service, and abnormal loads, and aircraft impact damage on } \\
\text { the structural, fire protection, and egress systems. }\end{array}$ \\
\hline $\begin{array}{l}\text { Mechanical and Metallurgical Analysis of } \\
\text { Structural Steel; Project Leader: Dr. Frank } \\
\text { W. Gayle }\end{array}$ & $\begin{array}{l}\text { Determine and analyze the mechanical and metallurgical properties } \\
\text { and quality of steel, weldments, and connections from steel } \\
\text { recovered from WTC } 1,2 \text {, and } 7 \text {. }\end{array}$ \\
\hline $\begin{array}{l}\text { Investigation of Active Fire Protection } \\
\text { Systems; Project Leader: Dr. David } \\
\text { D. Evans; Dr. William Grosshandler }\end{array}$ & $\begin{array}{l}\text { Investigate the performance of the active fire protection systems in } \\
\text { WTC } 1,2 \text {, and } 7 \text { and their role in fire control, emergency response, } \\
\text { and fate of occupants and responders. }\end{array}$ \\
\hline $\begin{array}{l}\text { Reconstruction of Thermal and Tenability } \\
\text { Environment; Project Leader: Dr. Richard } \\
\text { G. Gann }\end{array}$ & $\begin{array}{l}\text { Reconstruct the time-evolving temperature, thermal environment, } \\
\text { and smoke movement in WTC } 1,2 \text {, and } 7 \text { for use in evaluating the } \\
\text { structural performance of the buildings and behavior and fate of } \\
\text { occupants and responders. }\end{array}$ \\
\hline $\begin{array}{l}\text { Structural Fire Response and Collapse } \\
\text { Analysis; Project Leaders: Dr. John } \\
\text { L. Gross and Dr. Therese P. McAllister }\end{array}$ & $\begin{array}{l}\text { Analyze the response of the WTC towers to fires with and without } \\
\text { aircraft damage, the response of WTC } 7 \text { in fires, the performance } \\
\text { of composite steel-trussed floor systems, and determine the most } \\
\text { probable structural collapse sequence for WTC } 1,2 \text {, and } 7 \text {. }\end{array}$ \\
\hline $\begin{array}{l}\text { Occupant Behavior, Egress, and Emergency } \\
\text { Communications; Project Leader: Mr. Jason } \\
\text { D. Averill }\end{array}$ & $\begin{array}{l}\text { Analyze the behavior and fate of occupants and responders, both } \\
\text { those who survived and those who did not, and the performance of } \\
\text { the evacuation system. }\end{array}$ \\
\hline $\begin{array}{l}\text { Emergency Response Technologies and } \\
\text { Guidelines; Project Leader: Mr. J. Randall } \\
\text { Lawson }\end{array}$ & $\begin{array}{l}\text { Document the activities of the emergency responders from the time } \\
\text { of the terrorist attacks on WTC } 1 \text { and WTC } 2 \text { until the collapse of } \\
\text { WTC } 7 \text {, including practices followed and technologies used. }\end{array}$ \\
\hline
\end{tabular}




\section{NIST WTC Investigation Projects}

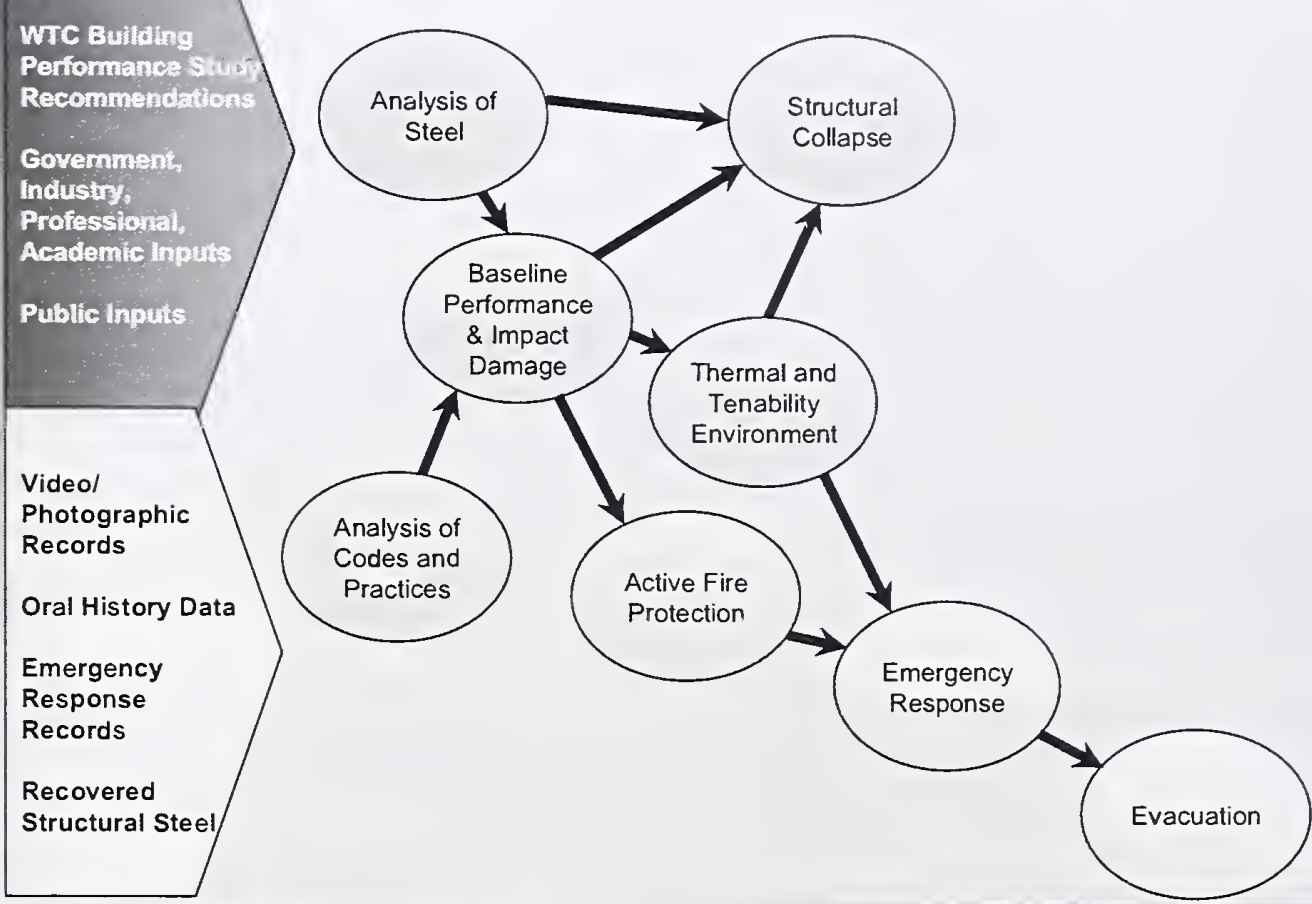

NLT

Figure P-1. The eight projects in the federal building and fire safety investigation of the WTC disaster.

\section{National Construction Safety Team Advisory Committee}

The NIST Director also established an advisory committee as mandated under the National Construction Safety Team Act. The initial members of the committee were appointed following a public solicitation. These were:

- Paul Fitzgerald, Executive Vice President (retired) FM Global, National Construction Safety Team Advisory Committee Chair

- John Barsom, President, Barsom Consulting, Ltd.

- John Bryan, Professor Emeritus, University of Maryland

- David Collins, President, The Preview Group, Inc.

- Glenn Corbett, Professor, John Jay College of Criminal Justice

- Philip DiNenno, President, Hughes Associates, Inc. 
- Robert Hanson, Professor Emeritus, University of Michigan

- Charles Thornton, Co-Chairman and Managing Principal, The Thornton-Tomasetti Group, Inc.

- Kathleen Tierney, Director, Natural Hazards Research and Applications Information Center, University of Colorado at Boulder

- Forman Williams, Director, Center for Energy Research, University of California at San Diego

This National Construction Safety Team Advisory Committee provided technical advice during the Investigation and commentary on drafts of the Investigation reports prior to their public release. NIST has benefited from the work of many people in the preparation of these reports, including the National Construction Safety Team Advisory Committee. The content of the reports and recommendations, however, are solely the responsibility of NIST.

\section{Public Outreach}

During the course of this Investigation, NIST held public briefings and meetings (listed in Table P-2) to solicit input from the public, present preliminary findings, and obtain comments on the direction and progress of the Investigation from the public and the Advisory Committee.

NIST maintained a publicly accessible Web site during this Investigation at http://wtc.nist.gov. The site contained extensive information on the background and progress of the Investigation.

\section{NIST's WTC Public-Private Response Plan}

The collapse of the WTC buildings has led to broad reexamination of how tall buildings are designed, constructed, maintained, and used, especially with regard to major events such as fires, natural disasters, and terrorist attacks. Reflecting the enhanced interest in effecting necessary change, NIST, with support from Congress and the Administration, has put in place a program, the goal of which is to develop and implement the standards, technology, and practices needed for cost-effective improvements to the safety and security of buildings and building occupants, including evacuation, emergency response procedures, and threat mitigation.

The strategy to meet this goal is a three-part NIST-led public-private response program that includes:

- A federal building and fire safety investigation to study the most probable factors that contributed to post-aircraft impact collapse of the WTC towers and the 47-story WTC 7 building, and the associated evacuation and emergency response experience.

- A research and development $(\mathrm{R} \& \mathrm{D})$ program to (a) facilitate the implementation of recommendations resulting from the WTC Investigation, and (b) provide the technical basis for cost-effective improvements to national building and fire codes, standards, and practices that enhance the safety of buildings, their occupants, and emergency responders. 
Table P-2. Public meetings and briefings of the WTC Investigation.

\begin{tabular}{|c|c|c|}
\hline Date & Location & Principal Agenda \\
\hline June 24,2002 & New York City, NY & $\begin{array}{l}\text { Public meeting: Public comments on the Draft Plan for the } \\
\text { pending WTC Investigation. }\end{array}$ \\
\hline August 21, 2002 & Gaithersburg, MD & Media briefing announcing the formal start of the Investigation. \\
\hline December 9, 2002 & Washington, DC & $\begin{array}{l}\text { Media briefing on release of the Public Update and NIST request } \\
\text { for photographs and videos. }\end{array}$ \\
\hline April 8, 2003 & New York City, NY & $\begin{array}{l}\text { Joint public forum with Columbia University on first-person } \\
\text { interviews. }\end{array}$ \\
\hline April 29-30,2003 & Gaithersburg, MD & $\begin{array}{l}\text { NCST Advisory Committee meeting on plan for and progress on } \\
\text { WTC Investigation with a public comment session. }\end{array}$ \\
\hline May 7,2003 & New York City, NY & Media briefing on release of May 2003 Progress Report. \\
\hline August 26-27, 2003 & Gaithersburg, MD & $\begin{array}{l}\text { NCST Advisory Committee meeting on status of the WTC } \\
\text { investigation with a public comment session. }\end{array}$ \\
\hline September 17,2003 & New York City, NY & $\begin{array}{l}\text { Media and public briefing on initiation of first-person data } \\
\text { collection projects. }\end{array}$ \\
\hline December $2-3,2003$ & Gaithersburg, MD & $\begin{array}{l}\text { NCST Advisory Committee meeting on status and initial results } \\
\text { and release of the Public Update with a public comment session. }\end{array}$ \\
\hline February 12,2004 & New York City, NY & $\begin{array}{l}\text { Public meeting on progress and preliminary findings with public } \\
\text { comments on issues to be considered in formulating final } \\
\text { recommendations. }\end{array}$ \\
\hline June 18,2004 & New York City, NY & Media/public briefing on release of June 2004 Progress Report. \\
\hline June $22-23,2004$ & Gaithersburg, MD & $\begin{array}{l}\text { NCST Advisory Committee meeting on the status of and } \\
\text { preliminary findings from the WTC Investigation with a public } \\
\text { comment session. }\end{array}$ \\
\hline August 24,2004 & Northbrook, IL & $\begin{array}{l}\text { Public viewing of standard fire resistance test of WTC floor } \\
\text { system at Underwriters Laboratories, lnc. }\end{array}$ \\
\hline October $19-20,2004$ & Gaithersburg, MD & $\begin{array}{l}\text { NCST Advisory Committee meeting on status and near complete } \\
\text { set of preliminary findings with a public comment session. }\end{array}$ \\
\hline November 22,2004 & Gaithersburg, MD & $\begin{array}{l}\text { NCST Advisory Committee discussion on draft annual report to } \\
\text { Congress, a public comment session, and a closed session to } \\
\text { discuss pre-draft recommendations for WTC Investigation. }\end{array}$ \\
\hline April 5, 2005 & New York City, NY & $\begin{array}{l}\text { Media and public briefing on release of the probable collapse } \\
\text { sequence for the WTC towers and draft reports for the projects on } \\
\text { codes and practices, evacuation, and emergency response. }\end{array}$ \\
\hline June 23,2005 & New York City, NY & $\begin{array}{l}\text { Media and public briefing on release of all draft reports for the } \\
\text { WTC towers and draft recommendations for public comment. }\end{array}$ \\
\hline $\begin{array}{l}\text { September 12-13, } \\
2005\end{array}$ & Gaithersburg, MD & $\begin{array}{l}\text { NCST Advisory Committee meeting on disposition of public } \\
\text { comments and update to draft reports for the WTC towers. }\end{array}$ \\
\hline $\begin{array}{l}\text { September 13-15, } \\
2005\end{array}$ & Gaithersburg, MD & $\begin{array}{l}\text { WTC Technical Conference for stakeholders and technical } \\
\text { community for dissemination of findings and recommendations } \\
\text { and opportunity for public to make technical comments. }\end{array}$ \\
\hline
\end{tabular}

- A dissemination and technical assistance program (DTAP) to (a) engage leaders of the construction and building community in ensuring timely adoption and widespread use of proposed changes to practices, standards, and codes resulting from the WTC Investigation and the R\&D program, and (b) provide practical guidance and tools to better prepare facility owners, contractors, architects, engineers, emergency responders, and regulatory authorities to respond to future disasters.

The desired outcomes are to make buildings, occupants, and first responders safer in future disaster events. 


\section{National Construction Safety Team Reports on the WTC Investigation}

A final report on the collapse of the WTC towers is being issued as NIST NCSTAR 1. A companion report on the collapse of WTC 7 is being issued as NIST NCSTAR 1A. The present report is one of a set that provides more detailed documentation of the Investigation findings and the means by which these technical results were achieved. As such, it is part of the archival record of this Investigation. The titles of the full set of Investigation publications are:

NIST (National Institute of Standards and Technology). 2005. Federal Building and Fire Safety Investigation of the World Trade Center Disaster: Final Report on the Collapse of the World Trade Center Towers. NIST NCSTAR 1. Gaithersburg, MD, September.

NIST (National Institute of Standards and Technology). 2006. Federal Building and Fire Safety Investigation of the World Trade Center Disaster: Final Report on the Collapse of World Trade Center 7. NIST NCSTAR 1A. Gaithersburg, MD.

Lew, H. S., R. W. Bukowski, and N. J. Carino. 2005. Federal Building and Fire Safety Investigation of the World Trade Center Disaster: Design, Construction, and Maintenance of Structural and Life Safety Systems. NIST NCSTAR 1-1. National Institute of Standards and Technology. Gaithersburg, MD, September.

Fanella, D. A., A. T. Derecho, and S. K. Ghosh. 2005. Federal Building and Fire Safety Investigation of the World Trade Center Disaster: Design and Construction of Structural Systems. NIST NCSTAR 1-1A. National Institute of Standards and Technology. Gaithersburg, MD, September.

Ghosh, S. K., and X. Liang. 2005. Federal Building and Fire Safety Investigation of the World Trade Center Disaster: Comparison of Building Code Structural Requirements. NIST NCSTAR 1-1B. National Institute of Standards and Technology. Gaithersburg, MD, September.

Fanella, D. A., A. T. Derecho, and S. K. Ghosh. 2005. Federal Building and Fire Safety Investigation of the World Trade Center Disaster: Maintenance and Modifications to Structural Systems. NIST NCSTAR 1-1C. National Institute of Standards and Technology. Gaithersburg, MD, September.

Grill, R. A., and D. A. Johnson. 2005. Federal Building and Fire Safety Investigation of the World Trade Center Disaster: Fire Protection and Life Safety Provisions Applied to the Design and Construction of World Trade Center 1, 2, and 7 and Post-Construction Provisions Applied after Occupancy. NIST NCSTAR 1-1D. National Institute of Standards and Technology. Gaithersburg, $\mathrm{MD}$, September.

Razza, J. C., and R. A. Grill. 2005. Federal Building and Fire Safety Investigation of the World Trade Center Disaster: Comparison of Codes, Standards, and Practices in Use at the Time of the Design and Construction of World Trade Center 1, 2, and 7. NIST NCSTAR 1-1E. National Institute of Standards and Technology. Gaithersburg, MD, September.

Grill, R. A., D. A. Johnson, and D. A. Fanella. 2005. Federal Building and Fire Safety Investigation of the World Trade Center Disaster: Comparison of the 1968 and Current (2003) New 
York City Building Code Provisions. N1ST NCSTAR 1-1F. National lnstitute of Standards and Technology. Gaithersburg, MD, Scptember.

Grill, R. A., and D. A. Johnson. 2005. Federal Building and Fire Safety Investigation of the World Trade Center Disaster: Anendments to the Fire Protection and Life Safety Provisions of the New York City Building Code by Local Laws Adopted While World Trade Center 1, 2, and 7 Were in Use. NIST NCSTAR 1-1G. National Institute of Standards and Technology. Gaithersburg, MD, September.

Grill, R. A., and D. A. Johnson. 2005. Federal Building and Fire Safety Investigation of the World Trade Center Disaster: Post-Construction Modifications to Fire Protection ana Life Safety Systems of World Trade Center 1 and 2. NIST NCSTAR 1-1H. National Institute of Standards and Technology. Gaithersburg, MD, September.

Grill, R. A., D. A. Johnson, and D. A. Fanella. 2005. Federal Building and Fire Safety Investigation of the World Trade Center Disaster: Post-Construction Modifications to Fire Protection, Life Safety, and Structural Systems of World Trade Center 7. NIST NCSTAR 1-11. National Institute of Standards and Technology. Gaithersburg, MD, September.

Grill, R. A., and D. A. Johnson. 2005. Federal Building and Fire Safety Investigation of the World Trade Center Disaster: Design, Installation, and Operation of Fuel System for Emergency Power in World Trade Center 7. NIST NCSTAR 1-1J. National Institute of Standards and Technology. Gaithersburg, MD, September.

Sadek, F. 2005. Federal Building and Fire Safety Investigation of the World Trade Center Disaster: Baseline Structural Performance and Aircraft Impact Danage Analysis of the World Trade Center Towers. NIST NCSTAR 1-2. National Institute of Standards and Technology. Gaithersburg, MD, September.

Faschan, W. J., and R. B. Garlock. 2005. Federal Building and Fire Safety Investigation of the World Trade Center Disaster: Reference Structural Models and Baseline Performance Analysis of the World Trade Center Towers. NIST NCSTAR 1-2A. National Institute of Standards and Technology. Gaithersburg, MD, September.

Kirkpatrick, S. W., R. T. Bocchieri, F. Sadek, R. A. MacNeill, S. Holmes, B. D. Peterson, R. W. Cilke, C. Navarro. 2005. Federal Building and Fire Safety Investigation of the World Trade Center Disaster: Analysis of Aircraft Impacts into the World Trade Center Towers, NIST

NCSTAR 1-2B. National Institute of Standards and Technology. Gaithersburg, MD, September.

Gayle, F. W., R. J. Fields, W. E. Luecke, S. W. Banovic, T. Foecke, C. N. McCowan, T. A. Siewert, and J. D. McColskey. 2005. Federal Building and Fire Safety Investigation of the World Trade Center Disaster: Mechanical and Metallurgical Analysis of Structural Steel. NIST NCSTAR 1-3. National Institute of Standards and Technology. Gaithersburg, MD, September.

Luecke, W. E., T. A. Siewert, and F. W. Gayle. 2005. Federal Building and Fire Safety Investigation of the World Trade Center Disaster: Contemporaneous Strnctural Steel Specifications. NIST Special Publication 1-3A. National Institute of Standards and Technology. Gaithersburg, MD, September. 
Banovic, S. W. 2005. Federal Building and Fire Safety Investigation of the World Trade Center Disaster: Steel Inventory and Identification. NIST NCSTAR 1-3B. National Institute of Standards and Technology. Gaithersburg, MD, September.

Banovic, S. W., and T. Foecke. 2005. Federal Building and Fire Safety Investigation of the World Trade Center Disaster: Damage and Failure Modes of Structural Steel Components. NIST NCSTAR 1-3C. National Institute of Standards and Technology. Gaithersburg, MD, September.

Luecke, W. E., J. D. McColskey, C. N. McCowan, S. W. Banovic, R. J. Fields, T. Foecke, T. A. Siewert, and F. W. Gayle. 2005. Federal Building and Fire Safety Investigation of the World Trade Center Disaster: Mechanical Properties of Structural Steels. NIST NCSTAR 1-3D. National Institute of Standards and Technology. Gaithersburg, MD, September.

Banovic, S. W., C. N. McCowan, and W. E. Luecke. 2005. Federal Building and Fire Safety Investigation of the World Trade Center Disaster: Physical Properties of Structural Steels. NIST NCSTAR 1-3E. National Institute of Standards and Technology. Gaithersburg, MD, September.

Evans, D. D., R. D. Peacock, E. D. Kuligowski, W. S. Dols, and W. L. Grosshandler. 2005. Federal Building and Fire Safety Investigation of the World Trade Center Disaster: Active Fire Protection Systems. NIST NCSTAR 1-4. National Institute of Standards and Technology. Gaithersburg, MD, September.

Kuligowski, E. D., D. D. Evans, and R. D. Peacock. 2005. Federal Building and Fire Safety Investigation of the World Trade Center Disaster: Post-Construction Fires Prior to September 11, 2001. NIST NCSTAR 1-4A. National Institute of Standards and Technology. Gaithersburg, MD, September.

Hopkins, M., J. Schoenrock, and E. Budnick. 2005. Federal Building and Fire Safety Investigation of the World Trade Center Disaster: Fire Suppression Systems. NIST NCSTAR 1-4B. National Institute of Standards and Technology. Gaithersburg, MD, September.

Keough, R. J., and R. A. Grill. 2005. Federal Building and Fire Safety Investigation of the World Trade Center Disaster: Fire Alarm Systems. NIST NCSTAR 1-4C. National Institute of Standards and Technology. Gaithersburg, MD, September.

Ferreira, M. J., and S. M. Strege. 2005. Federal Building and Fire Safety Investigation of the World Trade Center Disaster: Smoke Management Systems. NIST NCSTAR 1-4D. National Institute of Standards and Technology. Gaithersburg, MD, September.

Gann, R. G., A. Hamins, K. B. McGrattan, G. W. Mulholland, H. E. Nelson, T. J. Ohlemiller, W. M. Pitts, and K. R. Prasad. 2005. Federal Building and Fire Safety Investigation of the World Trade Center Disaster: Reconstruction of the Fires in the World Trade Center Towers. NIST NCSTAR 1-5. National Institute of Standards and Technology. Gaithersburg, MD, September.

Pitts, W. M., K. M. Butler, and V. Junker. 2005. Federal Building and Fire Safety Investigation of the World Trade Center Disaster: Visual Evidence, Damage Estimates, and Timeline Analysis. NIST NCSTAR 1-5A. National Institute of Standards and Technology. Gaithersburg, MD, September. 
Hamins, A., A. Maranghides, K. B. McGrattan, E. Johnsson, T. J. Ohlcmiller, M. Donnclly, J. Yang, G. Mulholland, K. R. Prasad, S. Kukuck, R. Anleitncr and T. McAllistcr. 2005. Federal Building and Fire Safety Investigation of the World Trade Center Disaster: Experiments and Modeling of Structural Steel Elements Exposed to Fire. NIST NCSTAR 1-5B. National Institutc of Standards and Technology. Gaithcrsburg, MD, Scptcmbcr.

Ohlemiller, T. J., G. W. Mulholland, A. Maranghides, J. J. Fillibcn, and R. G. Gann. 2005. Federal Building and Fire Safety Investigation of the World Trade Center Disaster: Fire Tests of Single Office Workstations. NIST NCSTAR 1-5C. National Institute of Standards and Technology. Gaithersburg, MD, September.

Gann, R. G., M. A. Riley, J. M. Repp, A. S. Whittaker, A. M. Rcinhorn, and P. A. Hough. 2005. Federal Building and Fire Safety Investigation of the World Trade Center Disaster: Reaction of Ceiling Tile Systems to Shocks. NIST NCSTAR 1-5D. National Institute of Standards and Technology. Gaithersburg, MD, September.

Hamins, A., A. Maranghides, K. B. McGrattan, T. J. Ohlemiller, and R. Anlcitner. 2005. Federal Building and Fire Safety Investigation of the World Trade Center Disaster: Experiments and Modeling of Multiple Workstations Burning in a Compartment. NIST NCSTAR 1-5E. National Institute of Standards and Technology. Gaithersburg, MD, September.

McGrattan, K. B., C. Bouldin, and G. Forney. 2005. Federal Building and Fire Safety Investigation of the World Trade Center Disaster: Computer Simulation of the Fires in the World Trade Center Towers. NIST NCSTAR 1-5F. National Institute of Standards and Technology. Gaithersburg, MD, September.

Prasad, K. R., and H. R. Baum. 2005. Federal Building and Fire Safety Investigation of the World Trade Center Disaster: Fire Structure Interface and Thermal Response of the World Trade Center Towers. NIST NCSTAR 1-5G. National Institute of Standards and Technology. Gaithersburg, $\mathrm{MD}$, September.

Gross, J. L., and T. McAllister. 2005. Federal Bnilding and Fire Safety Investigation of the World Trade Center Disaster: Structural Fire Response and Probable Collapse Sequence of the World Trade Center Towers. NIST NCSTAR 1-6. National Institute of Standards and Technology. Gaithersburg, MD, September.

Carino, N. J., M. A. Starnes, J. L. Gross, J. C. Yang, S. Kukuck, K. R. Prasad, and R. W. Bukowski. 2005. Federal Building and Fire Safety Investigation of the World Trade Center Disaster: Passive Fire Protection. NIST NCSTAR 1-6A. National Institute of Standards and Technology. Gaithersburg, MD, September.

Gross, J., F. Hervey, M. Izydorek, J. Mammoser, and J. Treadway. 2005. Federal Building and Fire Safety Investigation of the World Trade Center Disaster: Fire Resistance Tests of Floor Truss Systems. NIST NCSTAR 1-6B. National Institute of Standards and Technology. Gaithersburg, $\mathrm{MD}$, September.

Zarghamee, M. S., S. Bolourchi, D. W. Eggers, Ö. O. Erbay, F. W. Kan, Y. Kitane, A. A. Liepins, M. Mudlock, W. I. Naguib, R. P. Ojdrovic, A. T. Sarawit, P. R Barrett, J. L. Gross, and 
T. P. McAllister. 2005. Federal Building and Fire Safety Investigation of the World Trade Center Disaster: Component, Connection, and Subsystem Structural Analysis. NIST NCSTAR 1-6C. National Institute of Standards and Technology. Gaithersburg, MD, September.

Zarghamee, M. S., Y. Kitane, Ö. O. Erbay, T. P. McAllister, and J. L. Gross. 2005. Federal Building and Fire Safety Investigation of the World Trade Center Disaster: Global Structural Analysis of the Response of the World Trade Center Towers to Inpact Danage and Fire. NIST NCSTAR 1-6D. National Institute of Standards and Technology. Gaithersburg, MD, September.

McAllister, T., R. W. Bukowski, R. G. Gann, J. L. Gross, K. B. McGrattan, H. E. Nelson, L. Phan, W. M. Pitts, K. R. Prasad, F. Sadek. 2006. Federal Building and Fire Safety Investigation of the World Trade Center Disaster: Structural Fire Response and Probable Collapse Sequence of World Trade Center 7. (Provisional). NIST NCSTAR 1-6E. National Institute of Standards and Technology. Gaithersburg, MD.

Gilsanz, R., V. Arbitrio, C. Anders, D. Chlebus, K. Ezzeldin, W. Guo, P. Moloney, A. Montalva, J. Oh, K. Rubenacker. 2006. Federal Building and Fire Safety Investigation of the World Trade Center Disaster: Structural Analysis of the Response of World Trade Center 7 to Debris Damage and Fire. (Provisional). NIST NCSTAR 1-6F. National Institute of Standards and Technology. Gaithersburg, MD.

Kim, W. 2006. Federal Building and Fire Safety Investigation of the World Trade Center Disaster: Analysis of September 11, 2001, Seismogran Data. (Provisional). NIST NCSTAR 1-6G. National Institute of Standards and Technology. Gaithersburg, MD.

Nelson, K. 2006. Federal Building and Fire Safety Investigation of the World Trade Center Disaster: The Con Ed Substation in World Trade Center 7. (Provisional). NIST NCSTAR 1-6H. National Institute of Standards and Technology. Gaithersburg, MD.

Averill, J. D., D. S. Mileti, R. D. Peacock, E. D. Kuligowski, N. Groner, G. Proulx, P. A. Reneke, and H. E. Nelson. 2005. Federal Building and Fire Safety Investigation of the World Trade Center Disaster: Occupant Behavior, Egress, and Emergency Communication. NIST NCSTAR 1-7. National Institute of Standards and Technology. Gaithersburg, MD, September.

Fahy, R., and G. Proulx. 2005. Federal Building and Fire Safety Investigation of the World Trade Center Disaster: Analysis of Published Accounts of the World Trade Center Evacuation. NIST NCSTAR 1-7A. National Institute of Standards and Technology. Gaithersburg, MD, September.

Zmud, J. 2005. Federal Building and Fire Safety Investigation of the World Trade Center Disaster: Technical Documentation for Survey Administration. NIST NCSTAR 1-7B. National Institute of Standards and Technology. Gaithersburg, MD, September.

Lawson, J. R., and R. L. Vettori. 2005. Federal Building and Fire Safety Investigation of the World Trade Center Disaster: The Emergency Response Operations. NIST NCSTAR 1-8. National Institute of Standards and Technology. Gaithersburg, MD, September. 


\section{EXECUTIVE SUMMARY}

The purpose of this report is to identify the repairs and/or modifications made to the firc protection, life safety, and struetural framing systems of World Trade Centcr (WTC) 7 from initial occupancy to September 11, 2001. Documentation for more than 120 tenant alterations to WTC 7 was loeated and reviewed. Fire protection, life safety, and structural framing systems for these alterations are summarized in this report.

The fire protection and life safety systcms were modified to aecommodate new tenant layouts. As walls were removed, added, and relocated, the requirements for the fire protection and life safety systcms changed. As wall layouts were modified, fire sprinkler and fire alarm devices were reloeated. Fire and smoke dampers were installed as required by the Building Code of the City of New York (BCNYC). Life safety requirements of the BCNYC, such as travel distance requirements, were analyzed. A list is provided of the tenant alterations that modified the fire protection and life safety systems.

Most of the structural modifications were done to accommodate tenant requirements. Horizontal members of the floor framing system were strengthened due to increased loading from high-density files. Strengthening of these beams and girders was achieved by welding cover plates to the bottom flanges, the underside of the top flanges, or both. In some cases, new beams were introduced to carry a portion of the new load.

Floor slabs were completely removed on the east side of the building to aeeommodate trading floors for Salomon Brothers, Ine., but were subsequently replaeed when the trading floors were moved to another location. Columns in this area, which had twice the unsupported length after the slab removal, were reinforeed. Other openings were cut into a few floor levels to accommodate new stairways connecting adjoining floors.

Web openings were cut through some beams and girders to allow passage of ductility work. In some cases, the beams or girders had to be reinforced in order to increase eapaeity. 
This page intentionally left blank. 


\section{Chapter 1 \\ INTRODUCTION}

Over the life of World Trade Center (WTC) 7, enhancements to the fire protcction, life safety, and structural framing systems were made. Tenant altcrations, fires, revised building codc provisions, and new technology all were the rcasons for the enhancements of the systems. Changes madc to these systems ultimately affected the building performancc. Thus, in order to analyze the performance of WTC 7 in response to the attacks of September 11, 2001, it is crucial to have the most current configuration of the systems installed. The purpose of this report is to identify the repairs and/or modifications made to the fire protection, life safety, and structural framing systems of WTC 7 from initial occupancy to September 11, 2001.

\subsection{FIRE PROTECTION AND LIFE SAFETY}

Tenant alteration projects included modifications of the fire protection and life safety systems within WTC 7. Tenant spaces were modified to accommodate new floor layouts as tenants moved in and out. New wall layouts, changed occupancy use, and mission continuity objectives in tenant spaces introduced different code requirements.

Tenant alterations performed in WTC 7 included typical business occupancy modifications to the fire protection and life safety systems. A typical office alteration included rearranging walls to accommodate the desired layout of the tenant while maintaining proper fire separations and divisions from other tenants within the building. Fire and smoke dampers were installed in the heating, ventilating, and air conditioning systems where penetrations of fire rated walls occurred. The base building wet pipe sprinkler system was modified by the addition and/or relocation of sprinkler heads and branchlines in the tenant space as called for in National Fire Protection Association (NFPA) 13 and the Building Code of the City of New York (BCNYC) requirements for minimum spacing from these walls. Hydraulic calculations were performed to justify the pipe sizes of the branch lines as necessary. Documentation indicates that calculations were conducted back to the floor control valve assembly of each floor where system pressures were previously known. Fire alarm and voice communication systems were installed in accordance with NFPA 72 and the BCNYC requirements within each tenant space, again to maintain minimum spacing from relocated walls. Although documentation does not exist for each project, an egress analysis was generally performed to verify that travel distances and other means of egress requirements in the $\mathrm{BCNYC}$ were not exceeded. Providing exit and emergency lighting within the tenant space, which was required by the BCNYC, was also included in the tenant alteration project. The system modifications were submitted to the Port Authority of New York and New Jersey (PANYNJ or Port Authority) for approval or were approved using the self-certification process established by the PANYNJ. Tenant Construction Review Manuals, provided by the PANYNJ Engineering Department, were used for establishing minimum design criteria and design details.

Whenever work was done in the WTC buildings, a project number was assigned by the Port Authority under which all contracts, drawings, and correspondence was filed. These numbers are typically of the format W(yy)-1234 (where yy is the year initiated and 1234 is a four-digit number). This report includes 
these numbers as references to individual projects, and files retained by the Port Authority are identified by these numbers.

\subsection{STRUCTURAL FRAMING}

Most of the structural modifications were done to accommodate tenant requirements. These generally involved strengthening the horizontal members of the floor framing system due to increased loading from high-density files (see Table 3-1 in Chapter 3). Strengthening of the beams and girders was achieved by welding cover plates to the bottom flanges and/or to the underside of the top flanges. In some cases, deficiencies were remedied by introducing a new beam between existing beams to reduce the tributary load on the deficient beams. In other cases, wide-flange T-sections were welded directly to the underside of deficient girders.

Floor slabs were completely removed on the east side of the building to accommodate the trading floors for Salomon Brothers, Inc., but were subsequently replaced when the trading floors were moved to another location (Cantor 1989). The only framing members that remained on these floors from the original design were the columns and the girders that were part of the lateral-force-resisting system. The columns, which had twice the unsupported length after the slab removal, were reinforced in this area. Other openings were cut into a few floors to accommodate new stairways connecting adjoining floors. New framing members were introduced where needed.

Web openings were cut through some beams and girders to allow passage of utility ductwork. These openings were typically reinforced with plates. In some cases, an inverted T-section was welded to the bottom flange of the existing beam to increase the capacity of the beam in the area of the opening. Shallow notches were cut in the top and bottom flanges of some of the beams to accommodate ductwork. To make up for lost capacity, plates were introduced just under the top flanges and just above the bottom flanges.

Other minor modifications were made, including the installation of supports for folding partitions.

The remainder of this report identifies the specific major modifications and repairs that were made to the fire protection, life safety, and structural framing systems of WTC 7.

\section{$1.3 \quad$ REFERENCES}

Cantor (The Office of Irwin G. Cantor P.C.). 1989. "Salomon Brothers, Inc., Base Building Modifications - 7 World Trade Center Structural Computations." W-7004, Port Authority. Newark, January. 


\section{Chapter 2 \\ Modifications to Fire Protection And LifE SAFETy Systems}

The fire protection and life safety modifications of World Trade Center (WTC) 7 are listed in Table 2-1. Most of the tenant alterations followed the typical business occupancy modification summary previously identified in Chapter 1 of this report. Tenant alterations with additional modifications or modifications that varied from the typical modification summary of Chapter 1 are noted in the last column of Table 2-1. The year and floor location of the alteration are also given to provide a history of the floor or portion thereof. Tenant alteration documentation was not located for all floors, and thus, not every floor is identified in Table 2-1.

Table 2-1. Summary of modifications to WTC 7 fire protection and life safety systems.

\begin{tabular}{|l|c|c|c|l|l|}
\hline TAA No. & Floor(s) & $\begin{array}{c}\text { Location } \\
\text { on Floor }\end{array}$ & Year & \multicolumn{1}{|c|}{ Tenant } & \multicolumn{1}{|c|}{ Systems Modified } \\
\hline W98-1734 & 1 & Core & 1998 & $\begin{array}{l}\text { Office of Emergency } \\
\text { Management }\end{array}$ & $\begin{array}{l}\text { Typical, including Inergen system } \\
\text { for fuel tanks }\end{array}$ \\
\hline W-7005 & 2,4 & Northeast & 1989 & Salomon Brothers, lnc. & Typical \\
\hline W00-7108 & 3 & Core & 2000 & Salomon Snith Barney & Typical \\
\hline W-8006 & 3 & Southeast & 1990 & Tobacco Shop & Typical \\
\hline W95-7140 & 3 & Northeast & 1995 & Salomon Brothers, Inc. & Typical \\
\hline W98-7195 & 3 & Lobby & 1998 & WTC 7 & Egress analysis \\
\hline W00-7004 & $\begin{array}{l}4, \\
29-37,\end{array}$ & Various & 2002 & Salomon Smith Barney & $\begin{array}{l}\text { Various modifications, mostly } \\
\text { utilities and structural but includes } \\
\text { new halon system (34th floor) }\end{array}$ \\
\hline W99-7175 & 7 & Northeast & 1999 & American Express & Typical \\
\hline W98-1734 & 7 & South & 1998 & $\begin{array}{l}\text { Office of Emergency } \\
\text { Wanagement }\end{array}$ & $\begin{array}{l}\text { Removal of sprinklers from } \\
\text { generator room }\end{array}$ \\
\hline
\end{tabular}


Table 2-1. Summary of modifications to WTC 7 fire protection and life safety systems (continued).

\begin{tabular}{|c|c|c|c|c|c|}
\hline TAA No. & Floor(s) & $\begin{array}{l}\text { Location } \\
\text { on Floor }\end{array}$ & Year & Tenant & Systems Modified \\
\hline W93-7233 & 7,8 & Entire & 1994 & American Express & Typical \\
\hline W01-7131 & $7,8,13$ & Northwest & 2001 & Unknown & Typical \\
\hline W00-7143 & 8 & Northwest & 2000 & American Express & Typical \\
\hline W94-7187 & 8 & West & 1995 & $\begin{array}{l}\text { American Express Bank } \\
\text { Check Processing } \\
\text { Department }\end{array}$ & Typical \\
\hline $\begin{array}{l}\text { W94- } \\
7176.02\end{array}$ & 9,10 & Entire & 1994 & $\begin{array}{l}\text { Ambassador Construction } \\
\text { Project }\end{array}$ & Typical \\
\hline W-8005 & $10-12$ & Various & 1990 & Spicer and Oppenheimer & Typical \\
\hline W92-7056 & 11,12 & Entire & 1992 & $\begin{array}{l}\text { Securities Exchange } \\
\text { Commission }\end{array}$ & Typical \\
\hline W00-7185 & 13 & Southeast & 2000 & Standard Chartered & Typical \\
\hline W92-7056 & 13 & North & 1992 & $\begin{array}{l}\text { Securities Exchange } \\
\text { Commission }\end{array}$ & Typical \\
\hline W97-7202 & 13 & Northeast & 1997 & Salomon Brothers, Inc. & Typical \\
\hline W99-7137 & 13 & Northeast & 1999 & Standard Chartered & Typical \\
\hline $\begin{array}{l}\text { W96-7183, } \\
\text { W97-7150 }\end{array}$ & $14-16$ & Various & $\begin{array}{l}1996, \\
1997\end{array}$ & Insurance Services Office & Typical \\
\hline $\begin{array}{l}\text { W-8004, } \\
\text { W-8013, } \\
\text { W95-7110 }\end{array}$ & $14-17$ & Entire & $\begin{array}{l}1990, \\
1993, \\
1995\end{array}$ & Insurance Services Office & Typical \\
\hline W-7002 & 15 & Southeast & 1988 & Cameron and Colby & Typical \\
\hline W-8004 & 18 & Southwest & 1990 & Insurance Services Office & Typical \\
\hline W-8009 & 18 & Core & 1991 & Silverstein & Typical \\
\hline W92-7150 & 18 & Northeast & 1992 & $\begin{array}{l}\text { Equal Employment } \\
\text { Opportunity Commission }\end{array}$ & Typical \\
\hline
\end{tabular}


Table 2-1. Summary of modifications to WTC 7 fire protection and life safety systems (continued).

\begin{tabular}{|c|c|c|c|c|c|}
\hline TAA No. & Floor(s) & $\begin{array}{l}\text { Location } \\
\text { on Floor }\end{array}$ & Year & Tenant & Systems Modified \\
\hline W96-7189 & 18 & South & 1996 & Insurance Services Office & Typical \\
\hline W98-7203 & 18 & West & 1998 & $1 \mathrm{SO} 2$ & Typical \\
\hline $\mathrm{W}-8010$ & 19 & East & 1991 & Hartford lnsurance Group & Typical \\
\hline W96-7118 & 19 & West & 1996 & $\begin{array}{l}\text { National Association of } \\
\text { Insurance Commissioners }\end{array}$ & Typical \\
\hline W97-7101 & 19 & North & 1997 & ITT Hartford & Typical \\
\hline W95-7153 & 20 & Entire & 1995 & Hartford lnsurance Group & Typical \\
\hline W-8010 & 20,21 & Entire & 1991 & Hartford Insurance Group & Typical \\
\hline $\begin{array}{l}\text { W95-7179, } \\
\text { W95-7205 }\end{array}$ & 21 & East & $\begin{array}{l}1995 \\
1995\end{array}$ & 1TT Hartford & Typical \\
\hline W96-7150 & 21 & Southwest & 1996 & 1TT Hartford & Typical \\
\hline W97-7129 & 21 & West & 1997 & Salomon Brothers, lnc. & Typical \\
\hline W97-7135 & 21 & Core & 1997 & ITT Hartford & Typical \\
\hline W94-7107 & 22 & Entire & 1994 & $\begin{array}{l}\text { Federal Home Bank of } \\
\text { New York }\end{array}$ & $\begin{array}{l}\text { Typical, including new pre-action } \\
\text { system }\end{array}$ \\
\hline W98-7109 & 22 & Southwest & 1998 & $\begin{array}{l}\text { Federal Home Loan Bank } \\
\text { of New York }\end{array}$ & Typical \\
\hline W98-1734 & 23 & Entire & 1998 & $\begin{array}{l}\text { Office of Emergency } \\
\text { Management }\end{array}$ & $\begin{array}{l}\text { Typical, including new pre-action } \\
\text { system }\end{array}$ \\
\hline W-8003 & 24,25 & Entire & 1989 & $\begin{array}{l}\text { Department of Treasury - } \\
\text { IRS }\end{array}$ & Typical \\
\hline W95-7163 & 26,27 & Entire & 1995 & Standard Chartered & Typical \\
\hline $\begin{array}{l}\text { W93-7160, } \\
\text { W93-7138, } \\
\text { W93-7246 }\end{array}$ & 28 & Entire & 1993 & Salomon Brothers, Inc. & Typical \\
\hline W94-7180 & 28 & Northeast & 1994 & Salomon Brothers, Inc. & Typical \\
\hline
\end{tabular}


Table 2-1. Summary of modifications to WTC 7 fire protection and life safety systems (continued).

\begin{tabular}{|c|c|c|c|c|c|}
\hline TAA No. & Floor(s) & $\begin{array}{l}\text { Location } \\
\text { on Floor }\end{array}$ & Year & Tenant & Systems Modified \\
\hline W96-7185 & 28 & Various & 1996 & Salomon Brothers, Inc. & Typical \\
\hline $\begin{array}{l}\text { W97-7173, } \\
\text { W97-7186 }\end{array}$ & 28 & Various & $\begin{array}{l}1997 \\
1997\end{array}$ & Salomon Brothers, Inc. & Typical \\
\hline W99-7168 & $\begin{array}{c}28-32 \\
34\end{array}$ & Core & 1999 & Salomon Smith Barney & Typical \\
\hline W00-7194 & 29 & Southeast & 2000 & Hartford Insurance & Typical \\
\hline W93-7148 & 29 & Entire & 1993 & Salomon Brothers, Inc. & Typical \\
\hline W97-7172 & 29 & East & 1997 & Salomon Brothers, Inc. & Typical \\
\hline W00-7122 & 30 & Core & 2000 & Salomon Smith Barney & $\begin{array}{l}\text { Typical, including new pre-action } \\
\text { system }\end{array}$ \\
\hline W94-7141 & 30 & East & 1994 & Salomon Brothers, Inc. & Typical \\
\hline W94-7207 & 30 & East & 1994 & Salomon Brothers, Inc. & Typical \\
\hline W97-7132 & 30 & Southeast & 1997 & Salomon Brothers, Inc. & Typical \\
\hline W97-7152 & 30 & Southeast & 1997 & Department of Defense & Typical \\
\hline W00-7127 & 31 & Core & 2000 & Salomon Smith Barney & $\begin{array}{l}\text { Typical, including new pre-action } \\
\text { system }\end{array}$ \\
\hline W00-7128 & 32 & Core & 2000 & Salomon Smith Barney & $\begin{array}{l}\text { Typical, including new pre-action } \\
\text { system }\end{array}$ \\
\hline W00-7225 & 32 & Entire & 2000 & Salomon Smith Barney & Typical \\
\hline W93-7155 & 33 & Southwest & 1993 & Salomon Brothers, Inc. & Typical \\
\hline W93-7212 & 33 & South & 1994 & Salomon Brothers, Inc. & Typical \\
\hline W99-7160 & 33 & $\begin{array}{l}\text { Southwest } \\
\text { \& Core }\end{array}$ & 1999 & Salomon Smith Barney & Typical \\
\hline W99-7161 & 33 & Core & 1999 & Salomon Smith Barney & $\begin{array}{l}\text { Typical, including new pre-action } \\
\text { systems }\end{array}$ \\
\hline
\end{tabular}


Table 2-1. Summary of modifications to WTC 7 fire protection and life safety systems (continued).

\begin{tabular}{|c|c|c|c|c|c|}
\hline TAA No. & Floor(s) & $\begin{array}{l}\text { Location } \\
\text { on Floor }\end{array}$ & Year & Tenant & Systems Modified \\
\hline $\begin{array}{l}\text { W93-7137, } \\
\text { W93-7157, } \\
\text { W93-7207, } \\
\text { W93-7237, } \\
\text { W94-7134, } \\
\text { W94-7230 }\end{array}$ & 34 & Entire & $\begin{array}{l}1993, \\
1993, \\
1993, \\
1993, \\
1994, \\
1994\end{array}$ & Salomon Brothers, Inc. & Typical \\
\hline W97-7119 & 34 & South & 1997 & Salomon Brothers, lnc. & Typical \\
\hline W93-7151 & 35 & Southeast & 1993 & Salomon Brothers, lnc. & Typical \\
\hline W93-7231 & 35 & Southeast & 1994 & Salomon Brothers, Inc. & Typical \\
\hline W94-7195 & 35 & Southwest & 1994 & Salomon Brothers, Inc. & Typical \\
\hline W-7005 & 35,44 & Entire & 1989 & Salomon Brothers, Inc. & $\begin{array}{l}\text { Typical, including egress analysis } \\
\text { for assembly space }\end{array}$ \\
\hline W00-7139 & 36 & East & 2000 & Salomon Smith Barney & Typical \\
\hline W96-7196 & 36 & Various & 1996 & Salomon Brothers, Inc. & Typical \\
\hline W99-7122 & 36 & Northeast & 1999 & Salomon Smith Barney & Typical \\
\hline W99-7144 & 36,39 & Core & 1999 & Salomon Smith Barney & $\begin{array}{l}\text { Typical, including new pre-action } \\
\text { systems }\end{array}$ \\
\hline W99-7148 & $36-43$ & Core & 1999 & Salomon Smith Barney & $\begin{array}{l}\text { Typical, including new pre-action } \\
\text { systems }\end{array}$ \\
\hline W00-7188 & 37 & Entire & 2000 & Salomon Smith Barney & Typical \\
\hline W99-7134 & 37 & Entire & 1999 & Salomon Smith Barney & Typical \\
\hline W00-7224 & 38 & Northeast & 2000 & Salomon Smith Barney & Typical \\
\hline W94-7102 & 38 & Entire & 1994 & Salomon Brothers, Inc. & Typical \\
\hline W96-7179 & 38 & North & 1996 & Salomon Brothers, lnc. & Typical \\
\hline W97-7167 & 38 & Northeast & 1997 & Salomon Brothers, lnc. & Typical \\
\hline
\end{tabular}


Table 2-1. Summary of modifications to WTC 7 fire protection and life safety systems (continued).

\begin{tabular}{|c|c|c|c|c|c|}
\hline TAA No. & Floor(s) & $\begin{array}{l}\text { Location } \\
\text { on Floor }\end{array}$ & Year & Tenant & Systems Modified \\
\hline W00-7202 & 39 & Entire & 2000 & Salomon Smith Barney & Typical \\
\hline W93-7102 & 39 & Entire & 1993 & Salomon Brothers, lnc. & $\begin{array}{l}\text { Typical, includes egress analysis } \\
\text { for auditorium }\end{array}$ \\
\hline W95-7173 & 39 & Core & 1995 & Salomon Brothers, lnc. & Typical \\
\hline W96-7120 & 39 & Northeast & 1996 & Salomon Brothers, lnc. & Typical \\
\hline W97-7138 & 39 & Northeast & 1997 & Salomon Brothers lnc. & Typical \\
\hline W99-7119 & 39 & Northeast & 1999 & Salomon Smith Barney & Typical \\
\hline W99-7127 & $39-46$ & East & 1999 & Salomon Smith Barney & Typical \\
\hline W99-7172 & 40 & Entire & 1999 & Salomon Smith Barney & Typical \\
\hline W93-7118 & 41 & Northwest & 1993 & Salomon Brothers, lnc. & Typical \\
\hline W96-7140 & 41 & West & 1996 & Salomon Brothers, lnc. & Typical \\
\hline W97-7142 & 41 & Core & 1997 & Salomon Brothers, lnc. & Typical \\
\hline W97-7153 & 41 & North & 1997 & Salomon Brothers, lnc. & Typical \\
\hline W99-7177 & 41 & Entire & 1999 & Salomon Smith Barney & Typical \\
\hline W99-7178 & 42 & Entire & 1999 & Salomon Smith Barney & Typical \\
\hline W99-7178 & 42 & Entire & 1999 & Salomon Smith Barney & Typical \\
\hline W00-7111 & 43 & Entire & 2000 & Salomon Smith Barney & $\begin{array}{l}\text { Typical, including new pre-action } \\
\text { system }\end{array}$ \\
\hline W01-7111 & 44 & Entire & 2001 & Salomon Smith Barney & $\begin{array}{l}\text { Typical, including new pre-action } \\
\text { systems }\end{array}$ \\
\hline W95-7195 & 45 & North & 1995 & Salomon Brothers, lnc. & Typical \\
\hline
\end{tabular}


Table 2-1. Summary of modifications to WTC 7 fire protection and life safety systems (continued).

\begin{tabular}{|l|c|c|c|l|l|}
\hline TAA No. & Floor(s) & $\begin{array}{c}\text { Location } \\
\text { on Floor }\end{array}$ & Year & \multicolumn{1}{|c|}{ Tenant } & \multicolumn{1}{|c|}{ Systems Modified } \\
\hline W99-7120 & 45 & West & 1999 & Salomon Smith Barney & Typical \\
\hline W99-7194 & 45 & East & 1999 & Salomon Smith Barney & Typical \\
\hline $\begin{array}{l}\text { W93-7167, } \\
\text { W93-7168 }\end{array}$ & 46 & Entire & $\begin{array}{l}1993, \\
1993\end{array}$ & Salomon Brothers, lnc. & Typical \\
\hline W97-7196 & 46 & South & 1997 & Salomon Brothers, Inc. & Typical \\
\hline W00-7203 & 47 & Northeast & 2000 & Salomon Snith Barney & Typical \\
\hline W93-7221 & 47 & Northeast & 1994 & Salomon Brothers, lnc. & Typical \\
\hline W97-7140 & 47 & East & 1997 & Salomon Brothers, lnc. & Typical \\
\hline W00-7202 & 39 & Entire & 2000 & Salomon Smith Barney & Typical \\
\hline W93-7102 & 39 & Entire & 1993 & Salomon Brothers, lnc. & $\begin{array}{l}\text { Typical, includes egress analysis } \\
\text { for auditorium }\end{array}$ \\
\hline W95-7173 & 39 & Core & 1995 & Salomon Brothers, lnc. & Typical \\
\hline
\end{tabular}

Key: TAA, Tenant Alteration Application. 
This page intentionally left blank. 


\section{Chapter 3 \\ Structural Modifications due to Tenant Alterations}

Structural modifications due to tenant altcrations are listed in Table 3-1. Included is a bricf description of the work that was performed with respect to the modifications. In most cases, members werc reinforced to accommodate floor loads that were greater than the loads for which thesc membcrs wcre originally designed.

In all of the cases cited in Table 3-1, structural calculations werc included on the chcck of the existing structural members and on the design of new structural mcmbcrs. In the documents related to the 1988 modifications, there were comments madc by the Tenant Construction Review Unit of the Port Authority of New York and New Jersey (PANYNJ or Port Authority) in regard to the project submittal. Also included were responses from the structural engineer to the Port Authority on these comments. Similar documents are available for the modifications made in 1999 on the 40th floor, which include a copy of the Tenant Construction or Alteration Application that was submitted to the Port Authority on behalf of the tenant.

Table 3-1. Modifications made due to tenant alterations.

\begin{tabular}{|c|c|c|c|c|c|}
\hline Date & Floor(s) & Tenant & $\begin{array}{l}\text { Structural } \\
\text { Engineer }\end{array}$ & Description of Modification & $\begin{array}{c}\text { Reference } \\
\text { Work } \\
\text { Order } \\
\text { Number }\end{array}$ \\
\hline 1988 & 38 & $\begin{array}{l}\text { Salomon } \\
\text { Brothers, Inc. }\end{array}$ & $\begin{array}{l}\text { Office of } \\
\text { Irwin G. } \\
\text { Cantor }\end{array}$ & $\begin{array}{l}\text { Bottom and top cover plates were } \\
\text { added to the existing W } 24 \times 55 \text { beams } \\
\text { along colunn lines } 37 \text { and } 40 \text {, and } \\
\text { bottom cover plates were added to the } \\
\text { existing W } 24 \times 55 \text { beams along colunn } \\
\text { lines } 30 \text { and } 35 \text { to support new hanger } \\
\text { loads. }\end{array}$ & $\begin{array}{l}\text { W-7004 } \\
\text { PANYNJ } \\
\text { (Newark) }\end{array}$ \\
\hline 1989 & 24 & $\begin{array}{l}\text { General } \\
\text { Auditing } \\
\text { Office }\end{array}$ & $\begin{array}{l}\text { Office of } \\
\text { Irwin G. } \\
\text { Cantor }\end{array}$ & $\begin{array}{l}\text { Bottom cover plates were added to the } \\
\text { existing W2 lx44 beam on column line } \\
45 \text { and the two adjacent W2 Ix } 44 \text { beams } \\
\text { to the west of column line } 45 \text { to support } \\
\text { additional load due to new file storage. } \\
\text { The existing W } 36 \times \text { I } 35 \text { girder framing } \\
\text { between columns } 76 \text { and } 79 \text {, which } \\
\text { supported these beams, was also } \\
\text { reinforced with a bottom cover plate. }\end{array}$ & $\begin{array}{l}\text { W-8003 } \\
\text { PANYNJ } \\
\text { (Newark) }\end{array}$ \\
\hline
\end{tabular}


Table 3-1. Modifications made due to tenant alterations (continued).

\begin{tabular}{|c|c|c|c|c|c|}
\hline Date & Floor(s) & Tenant & $\begin{array}{l}\text { Structural } \\
\text { Engineer }\end{array}$ & Description of Modification & $\begin{array}{l}\text { Reference } \\
\text { Work } \\
\text { Order } \\
\text { Number }\end{array}$ \\
\hline 1989 & 47 & $\begin{array}{l}\text { Salomon } \\
\text { Brothers, lnc. }\end{array}$ & $\begin{array}{l}\text { Office of } \\
\text { Irwin G. } \\
\text { Cantor }\end{array}$ & 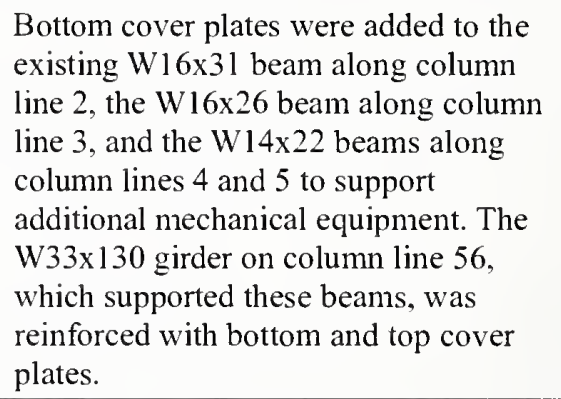 & $\begin{array}{l}\text { W-7004 } \\
\text { PANYNJ } \\
\text { (Newark) }\end{array}$ \\
\hline 1990 & 11,12 & $\begin{array}{l}\text { Spicer \& } \\
\text { Oppenheimer }\end{array}$ & $\begin{array}{l}\text { Office of } \\
\text { lrwin G. } \\
\text { Cantor }\end{array}$ & $\begin{array}{l}\text { Bottom cover plates were added to } \\
\text { eight existing beams and girders in the } \\
\text { northwest corner of the building on the } \\
11 \text { th floor to support larger live loads. } \\
\text { Similarly, bottom cover plates were } \\
\text { added to three existing beams between } \\
\text { column lines } 48 \text { and } 49 \text { and the girder } \\
\text { between columns } 70 \text { and } 73 \text { on the } 12 \text { th } \\
\text { floor. }\end{array}$ & $\begin{array}{l}\text { W-8005 } \\
\text { PANYNJ } \\
\text { (Newark) }\end{array}$ \\
\hline 1991 & 19 & ITT Hartford & $\begin{array}{l}\text { Office of } \\
\text { James } \\
\text { Ruderman }\end{array}$ & $\begin{array}{l}\text { Bottom cover plates were added to } \\
\text { existing W } 24 \times 55 \text { and } W 24 \times 76 \text { beams } \\
\text { to support new files and shelves. Exact } \\
\text { location of these beams could not be } \\
\text { determined from the documentation. }\end{array}$ & $\begin{array}{l}\text { W-8010 } \\
\text { PANYNJ } \\
\text { (Newark) }\end{array}$ \\
\hline 1992 & 12 & $\begin{array}{l}\text { Securities } \\
\text { Exchange } \\
\text { Conmission }\end{array}$ & $\begin{array}{l}\text { Office of } \\
\text { lrwin G. } \\
\text { Cantor }\end{array}$ & $\begin{array}{l}\text { Bottom cover plates were added to } \\
\text { eleven existing beams in the northwest } \\
\text { corner of the building to support legal } \\
\text { files. A new W } 12 \times 19 \text { beam was also } \\
\text { added between two of the existing } \\
\text { beams. }\end{array}$ & $\begin{array}{l}\text { W92-7056 } \\
\text { PANYNJ } \\
\text { (Newark) }\end{array}$ \\
\hline 1992 & 18,19 & $\begin{array}{l}\text { Equal } \\
\text { Employment } \\
\text { Opportunity } \\
\text { Commission }\end{array}$ & $\begin{array}{l}\text { Office of } \\
\text { Irwin G. } \\
\text { Cantor }\end{array}$ & $\begin{array}{l}\text { Bottom cover plates were added to } \\
\text { existing W24 beams on the } 18 \text { th floor } \\
\text { on column lines } 31,32 \text {, and } 33 \text { to } \\
\text { support larger live loads. }\end{array}$ & W92-7150 \\
\hline 1993 & 28 & $\begin{array}{l}\text { Salomon } \\
\text { Brothers, lnc. }\end{array}$ & $\begin{array}{l}\text { Office of } \\
\text { lrwin G. } \\
\text { Cantor }\end{array}$ & $\begin{array}{l}\text { Eight additional shear studs were added } \\
\text { to an existing W } 16 \times 26 \text { beam located in } \\
\text { the mechanical/electrical room to } \\
\text { support new equipment loads. }\end{array}$ & $\begin{array}{l}\text { W93-7138 } \\
\text { PANYNJ } \\
\text { (Newark) }\end{array}$ \\
\hline 1993 & 7,8 & $\begin{array}{l}\text { American } \\
\text { Express Bank }\end{array}$ & $\begin{array}{l}\text { Office of } \\
\text { James } \\
\text { Ruderman }\end{array}$ & $\begin{array}{l}\text { A new W } 12 \times 14 \text { beam located on the } \\
\text { west side of the building between } \\
\text { column lines } 7 \text { and } 8 \text { was added on the } \\
\text { 8th floor to support a new concrete } \\
\text { masonry unit wall. }\end{array}$ & $\begin{array}{l}\text { W93-7233 } \\
\text { PANYNJ } \\
\text { (Newark) }\end{array}$ \\
\hline
\end{tabular}


Table 3-1. Modifications made due to tenant alterations (continued).

\begin{tabular}{|c|c|c|c|c|c|}
\hline Date & Floor(s) & Tenant & $\begin{array}{l}\text { Structural } \\
\text { Engineer }\end{array}$ & Description of Modification & $\begin{array}{c}\text { Reference } \\
\text { Work } \\
\text { Order } \\
\text { Number }\end{array}$ \\
\hline 1994 & $7-29$ & $\begin{array}{l}\text { Salomon } \\
\text { Brothers, lnc. }\end{array}$ & $\begin{array}{l}\text { Office of } \\
\text { lrwin G. } \\
\text { Cantor }\end{array}$ & $\begin{array}{l}\text { Bottom cover plates were added to } \\
22 \text { existing beams between columns } 5 \\
\text { and } 25 \text { on the south side of the building } \\
\text { on each floor between levels } 7 \text { and } 29 \\
\text { to support larger live loads. Similarly, } \\
\text { bottom cover plates were added to eight } \\
\text { beams on the east side of the building } \\
\text { between column lines } 31 \text { and } 37 \text { on } \\
\text { each of these floors. }\end{array}$ & W93-7232 \\
\hline 1995 & 20 & 1TT Hartford & $\begin{array}{l}\text { The Cantor } \\
\text { Seinuk } \\
\text { Group }\end{array}$ & 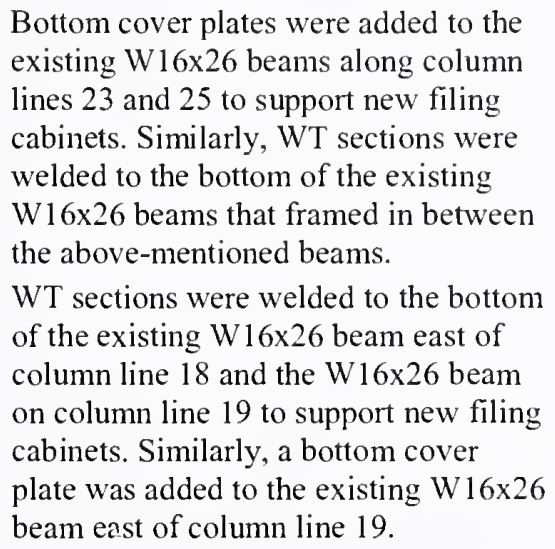 & W95-7153 \\
\hline 1999 & 37 & $\begin{array}{l}\text { Salomon } \\
\text { Smith Barney }\end{array}$ & $\begin{array}{l}\text { Gilsanz } \\
\text { Murray } \\
\text { Steficek }\end{array}$ & $\begin{array}{l}\text { A new W16x } 40 \text { beam was added } \\
\text { between two existing W } 14 \times 22 \text { beams } \\
\text { along column lines } 76 \text { and } 77 \text { to } \\
\text { support a new high-density filing } \\
\text { system. }\end{array}$ & $\begin{array}{l}\text { W99-7134 } \\
\text { PANYNJ } \\
\text { (Newark) }\end{array}$ \\
\hline 1999 & 13 & $\begin{array}{l}\text { The Standard } \\
\text { Chartered } \\
\text { Bank }\end{array}$ & $\begin{array}{l}\text { The Cantor } \\
\text { Seinuk } \\
\text { Group }\end{array}$ & $\begin{array}{l}\text { Ten additional shear studs were added } \\
\text { to an existing W } 24 \times 55 \text { beam to support } \\
\text { additional loads from a new file room } \\
\text { and a new UPS/LAN room. Exact } \\
\text { location of this beam could not be } \\
\text { determined from the documentation. }\end{array}$ & $\begin{array}{l}\text { W99- } \\
7137-02 \\
\text { PANYNJ } \\
\text { (Newark) }\end{array}$ \\
\hline 1999 & 40 & $\begin{array}{l}\text { Salomon } \\
\text { Smith Barney }\end{array}$ & $\begin{array}{l}\text { Gilsanz } \\
\text { Murray } \\
\text { Steficek }\end{array}$ & $\begin{array}{l}\text { Four new W18x35 beams were added } \\
\text { to support the new high-density files } \\
\text { near column } 76 \text {. WT } 4 \times 20 \text { sections were } \\
\text { welded to the bottom of two existing } \\
\text { W } 14 \times 22 \text { beams that supported the files. } \\
\text { New W16x50 beams were connected } \\
\text { below to the existing W } 36 \times 135 \text { girders } \\
\text { that supported the beams in this area. }\end{array}$ & $\begin{array}{l}\text { W99-7172 } \\
\text { PANYNJ } \\
\text { (Newark) }\end{array}$ \\
\hline
\end{tabular}


Table 3-1. Modifications made due to tenant alterations (continued).

\begin{tabular}{|c|c|c|c|c|c|}
\hline Date & Floor(s) & Tenant & $\begin{array}{l}\text { Structural } \\
\text { Engineer }\end{array}$ & Description of Modification & $\begin{array}{c}\text { Reference } \\
\text { Work } \\
\text { Order } \\
\text { Number }\end{array}$ \\
\hline 2000 & 31 & $\begin{array}{l}\text { Salomon } \\
\text { Smith Barney }\end{array}$ & $\begin{array}{l}\text { Gilsanz } \\
\text { Murray } \\
\text { Steficek }\end{array}$ & $\begin{array}{l}\text { Top and bottom cover plates were } \\
\text { added to an existing W27x94 beam } \\
\text { between columns } 77 \text { and } 80 \text { to support } \\
\text { a new high-density filing system. The } \\
\text { existing beam connections were also } \\
\text { reinforced with stiffened seat } \\
\text { connections. }\end{array}$ & $\begin{array}{l}\text { W00-7122 } \\
\text { PANYNJ } \\
\text { (Newark) }\end{array}$ \\
\hline 2000 & 38 & $\begin{array}{l}\text { Salomon } \\
\text { Smith Barney }\end{array}$ & $\begin{array}{l}\text { Gilsanz } \\
\text { Murray } \\
\text { Steficek }\end{array}$ & 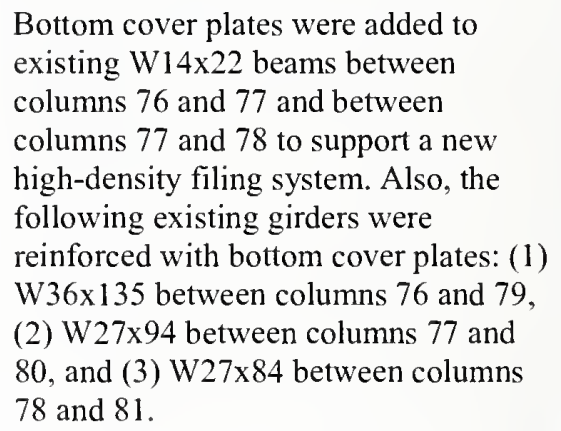 & $\begin{array}{l}\text { W00-7224 } \\
\text { PANYNJ } \\
\text { (Newark) }\end{array}$ \\
\hline 2000 & 39 & $\begin{array}{l}\text { Salomon } \\
\text { Snith Barney }\end{array}$ & $\begin{array}{l}\text { Gilsanz } \\
\text { Murray } \\
\text { Steficek }\end{array}$ & $\begin{array}{l}\text { New W14x53 beams were added under } \\
\text { each rail of a new high-density filing } \\
\text { system in lieu of reinforcing existing } \\
\text { W } 14 \times 22 \text { beams between columns } 76 \\
\text { and } 77 \text {. }\end{array}$ & $\begin{array}{l}\text { W00-7202 } \\
\text { PANYNJ } \\
\text { (Newark) }\end{array}$ \\
\hline
\end{tabular}

Key: WT, wide-flange T-sections. 


\section{Chapter 4 \\ OPENINGS MADE IN FLOOR SLABS}

\subsection{DESCRIPTION OF THE MODIFICATIONS}

According to the Base Building modifications (Cantor 1989) for World Trade Center 7, columns 76, 78, 79,80 , and 81 were reinforced with plates that ran from the top of the 39 th floor to the underside of the 40 th floor due to the removal of the floor slab at the 39 th floor. Similarly, column 74 was reinforced with plates that ran from the top of the 43rd floor to the underside of the 44th floor due to the removal of the floor slab at the 43rd floor. These slabs were removed to accommodatc the trading floors for Salomon Brothers, Inc. Furthermore, it is stated in the Facility Condition Survey Program report (PANYNJ 1997), that the 41 st and 43rd floor slabs were completely removed on the east side of the building to accommodate the trading floors for Salomon Brothers, Inc. Structural modifications involving openings made in the floor slabs are listed in Table 4-1. Included is a brief description of the work that was performed with respect to the modifications.

Table 4-1. Openings made in floor slabs.

\begin{tabular}{|c|c|c|c|c|c|}
\hline Date & Floor(s) & Tenant & $\begin{array}{c}\text { Structural } \\
\text { Engineer }\end{array}$ & Description of Modification & $\begin{array}{l}\text { Reference } \\
\text { Work } \\
\text { Order } \\
\text { Number }\end{array}$ \\
\hline 1989 & 3,4 & $\begin{array}{l}\text { Salomon } \\
\text { Brothers, Inc. }\end{array}$ & $\begin{array}{l}\text { Skidmore, } \\
\text { Owings \& } \\
\text { Merrill }\end{array}$ & $\begin{array}{l}\text { On the } 3 \text { rd floor, openings were cut on } \\
\text { the west, north, and east sides of the } \\
\text { building. New framing was introduced } \\
\text { around these openings. On the } 4 \text { th } \\
\text { floor, new openings and framing were } \\
\text { introduced on the north side of the } \\
\text { building. }\end{array}$ & $\begin{array}{l}\text { W-7004 } \\
\text { PANYNJ }\end{array}$ \\
\hline 1989 & 3 & $\begin{array}{l}\text { Salomon } \\
\text { Brothers, Inc. }\end{array}$ & $\begin{array}{l}\text { Office of } \\
\text { Irwin G. } \\
\text { Cantor }\end{array}$ & $\begin{array}{l}\text { Two } 2 \mathrm{ft} 6 \text { in. by } 3 \mathrm{ft} 6 \text { in. openings } \\
\text { were cut near columns } 24 \text { and } 25 \text {. New } \\
\text { C } 8 \times 11.5 \text { framing members were added } \\
\text { around the openings. }\end{array}$ & $\begin{array}{l}\text { W-7005 } \\
\text { PANYNJ } \\
\text { (Newark) }\end{array}$ \\
\hline 1990 & 11 & $\begin{array}{l}\text { Spicer \& } \\
\text { Oppenheimer }\end{array}$ & $\begin{array}{l}\text { Office of } \\
\text { Irwin G. } \\
\text { Cantor }\end{array}$ & $\begin{array}{l}\text { A new stair opening was made between } \\
\text { columns } 77,78,80 \text {, and } 81 \text {. New } \\
\text { W } 12 \times 16 \text { beams were added around the } \\
\text { opening. }\end{array}$ & $\begin{array}{l}\text { W-8005 } \\
\text { PANYNJ } \\
\text { (Newark) }\end{array}$ \\
\hline 1994 & 43 & $\begin{array}{l}\text { Salomon } \\
\text { Brothers, Inc. }\end{array}$ & $\begin{array}{l}\text { Skidmore, } \\
\text { Owings \& } \\
\text { Merrill }\end{array}$ & $\begin{array}{l}\text { A new slab opening was made near } \\
\text { column } 71 \text { in the core area. New } \\
\text { beams were added around the opening. }\end{array}$ & W94-7746 \\
\hline
\end{tabular}

Note: Structural calculations on the design of new structural members and on the check of the existing structural members were included for the modification made in 1989 (3rd floor) and 1990. 


\subsection{REFERENCES}

Cantor (The Office of Irwin G. Cantor P.C.). 1989. "Salomon Brothers, Inc., Base Building Modifications - 7 World Trade Center Structural Computations." W-7004, Port Authority. Newark, January.

PANYNJ (The Port Authority of New York and New Jersey). 1997. Port Authority Facility Condition Survey Program - 7 World Trade Center. Engineering Quality Assurance Division, Engineering Department. April. 


\section{Chapter 5 \\ Modifications MAdE to BeAm Webs and FLANGES}

Modifieations made to beam webs and flanges are summarized in Table 5-1. Ineluded is a brief deseription of the work that was performed with respeet to the modifieations.

Table 5-1. Modifications made to beam webs and flanges.

\begin{tabular}{|c|c|c|c|c|c|}
\hline Date & Floor(s) & Tenant & $\begin{array}{c}\text { Structural } \\
\text { Engineer }\end{array}$ & Description of Modification & $\begin{array}{l}\text { Reference } \\
\text { Work } \\
\text { Order } \\
\text { Number }\end{array}$ \\
\hline 1993 & 28 & $\begin{array}{l}\text { Salomon } \\
\text { Brothers, Inc. }\end{array}$ & $\begin{array}{l}\text { Office of } \\
\text { Irwin } \mathrm{G} \text {. } \\
\text { Cantor }\end{array}$ & $\begin{array}{l}\text { Two } 1 \text { in. by } 36 \text { in. openings, located } \\
3 \mathrm{ft} \text { apart, were cut into the web of an } \\
\text { existing W } 24 \times 55 \text { beam (unknown } \\
\text { location). Plates were welded on each } \\
\text { side of the web along the upper and } \\
\text { lower edges of the openings. }\end{array}$ & $\begin{array}{l}\text { W93-7138 } \\
\text { PANYNJ } \\
\text { (Newark) }\end{array}$ \\
\hline 1993 & $\begin{array}{c}4-7,16,21 \\
29,38,45\end{array}$ & $\begin{array}{l}\text { Salomon } \\
\text { Brothers, Inc. }\end{array}$ & $\begin{array}{l}\text { Office of } \\
\text { Irwin } \mathrm{G} \text {. } \\
\text { Cantor }\end{array}$ & $\begin{array}{l}\text { Notches were cut in the bottom flanges } \\
\text { of various beams on these floors to } \\
\text { accommodate ductwork. Plates were } \\
\text { welded to the upper side of the bottom } \\
\text { flanges. }\end{array}$ & W93-7221 \\
\hline 1998 & 1 & $\begin{array}{l}\text { Mayor's } \\
\text { Office of } \\
\text { Emergency } \\
\text { Management }\end{array}$ & $\begin{array}{l}\text { The Cantor } \\
\text { Seinuk } \\
\text { Group }\end{array}$ & $\begin{array}{l}\text { A notch was cut into the top flange of } \\
\text { an existing beam (unknown location). } \\
\text { Two plates, one on each side of the } \\
\text { web, were welded under the top flange. }\end{array}$ & W98-1734 \\
\hline 1999 & $36-44$ & $\begin{array}{l}\text { Salomon } \\
\text { Smith Barney }\end{array}$ & $\begin{array}{l}\text { The Cantor } \\
\text { Seinuk } \\
\text { Group }\end{array}$ & $\begin{array}{l}\text { Two new openings ( } 68 \text { in. by } 22 \text { in. and } \\
76 \text { in. by } 22 \text { in.) spaced } 3 \mathrm{ft} 10 \mathrm{in.} \text { apart } \\
\text { were cut into the web of the existing } \\
\text { W } 24 \times 62 \text { beam framing into column } 75 \text {. } \\
\text { Horizontal and vertical stiffener plates } \\
\text { were added on all sides of the openings. } \\
\text { Also, a new WT } 15 \times 74 \text { section was } \\
\text { welded to the bottom of the beam. The } \\
\text { same size openings were made in an } \\
\text { existing W } 27 \times 94 \text { beam on the } 43 \mathrm{rd} \\
\text { floor, which was reinforced in a similar } \\
\text { manner. }\end{array}$ & $\begin{array}{l}\text { W99-7127 } \\
\text { PANYNJ } \\
\text { (Newark) }\end{array}$ \\
\hline 1999 & 42,44 & $\begin{array}{l}\text { Salomon } \\
\text { Smith Barney }\end{array}$ & Gensler & $\begin{array}{l}\text { New web openings were cut in } \\
\text { numerous beams along the north and } \\
\text { east sides of the building. }\end{array}$ & W99-7127 \\
\hline
\end{tabular}


This page intentionally left blank. 

